\title{
Stability of symbiotic dinoflagellate type in the octocoral Briareum asbestinum
}

\author{
Andrew R. Hannes ${ }^{1}$, Marcos Barbeitos ${ }^{1}$, Mary Alice Coffroth ${ }^{2, *}$ \\ ${ }^{1}$ Department of Biological Sciences, State University of New York at Buffalo, Buffalo, New York 14260, USA \\ ${ }^{2}$ Graduate Program in Evolution Ecology and Behavior and Department of Geology, State University of \\ New York at Buffalo, Buffalo, New York 14260, USA
}

\begin{abstract}
Coral bleaching - the loss of photosynthetic algal symbionts from their cnidarian hosts - can lead to coral mortality and subsequent reef degradation. To understand the phenomenon of coral bleaching it is imperative to understand natural fluctuations in symbiotic dinoflagellate diversity and density. In this study, Symbiodinium type, based on length variation in domain V of the chloroplast large subunit of rDNA (cp23S rDNA), and cell densities were followed in 2 populations of the octocoral Briareum asbestinum over 1 yr. Symbiodinium type varied little over the course of the study despite anomalously cold sea surface temperatures during January 2003, when B. asbestinum populations experienced a significant loss of symbionts. This provides some of the first evidence that Caribbean octocorals are susceptible to cold-water bleaching events. Furthermore, the symbiont stability observed within $B$. asbestinum contributes to an increasing number of studies suggesting that many zooxanthellate coral species may not respond to fluctuating environments by changing symbionts.
\end{abstract}

KEY WORDS: Bleaching $\cdot$ Coral $\cdot$ Symbiodinium $\cdot$ Symbiosis $\cdot$ Zooxanthellae $\cdot$ Diversity

\section{INTRODUCTION}

Over the past 2 decades the condition of coral reefs worldwide has attracted universal attention and the increased incidence of coral bleaching, defined as the loss of symbiotic algae (dinoflagellates within the genus Symbiodinium) or their pigmentation, has been especially alarming. Bleaching has been linked to thermal stress, high ultraviolet light exposure, sedimentation, disease and low salinity (Glynn \& D'Croz 1990, Gleason \& Wellington 1993, Douglas 2003). Symbiotic dinoflagellates provide vital contributions to coral nutrition and physiology (Muscatine 1990) and loss of these algal symbionts (i.e. bleaching) often results in host death. Several studies have tracked symbiont cell densities in scleractinians and octocorals during natural seasonal changes in temperature and irradiance levels (Coles \& Jokiel 1978, Glynn \& D'Croz 1990, Fitt \& Warner 1995, Fitt et al. 2000, Lasker 2003) and a few studies report on temporal variation in symbiont diversity within their cnidarian host (Goulet \&
Coffroth 2003a, Chen et al. 2005, Thornhill et al. $2006 a, b)$. However, there are no studies that examine the fluctuation of these characteristics together in octocorals, which are often the dominant cnidarians on reefs (Lasker \& Coffroth 1983, Sanchez et al. 2003).

The genus Symbiodinium is a heterogeneous group of many species and strains that display different infectivity, behavior, ultrastructure, molecular characteristics and physiologies (reviewed in Trench 1997, Rowan 1998, Baker 2003, Coffroth \& Santos 2005, Stat et al. 2006). This diversity is found not only among host taxa, but also, in some instances, within a single host species (reviewed in Goulet 2006, Baker \& Romanski 2007). For example, in some host taxa the complement of Symbiodinium varies with fluctuating thermal and irradiance levels (Rowan et al. 1997, Baker 2001, Toller et al. 2001, van Oppen et al. 2001, Berkelmans \& van Oppen 2006, Oliver \& Palumbi 2009). This raises the possibility of seasonal change in symbiont composition. Temporal variation has been examined among scleractinian corals where symbiont assemblages varied seasonally 
in some species (Chen et al. 2005), while in many cases no seasonal pattern was discerned in studies over 3 and 5 yr periods (Thornhill et al. 2006a,b) or during extreme temperature fluctuations over the course of a year (Rodriguez-Lanetty et al. 2003).

Decreases in the density of symbiotic dinoflagellates are generally proportional to increases in temperature (Coles \& Jokiel 1978, Glynn \& D'Croz 1990, Fitt \& Warner 1995). In a 2 to 5 yr study of 5 scleractinian species, Fitt et al. (2000) found the lowest densities of symbiotic dinoflagellates at the end of the summer season when seawater temperatures were high (termed 'seasonal bleaching' by Fitt et al. 2000). Aside from seasonal bleaching, there are numerous studies documenting, forecasting and modeling widespread bleaching events caused by anomalously warm seasurface temperatures (SSTs) (reviewed in Hughes et al. 2003, McWilliams et al. 2005, Donner et al. 2007, Carpenter et al. 2008); however, there are few reports detailing the effects of anomalously cold SST's (Shinn 1966, Porter et al. 1982, Hoegh-Guldberg et al. 2005).

Abnormally warm and cold temperatures affect photosynthetic organisms by increasing photoinhibition, eventually leading to cellular damage (Lyons 1973, Krause 1992). Saxby et al. (2003) provided evidence that corals exposed to reduced temperatures $\left(\leq 14^{\circ} \mathrm{C}\right)$ experience similar physiological symptoms as those exposed to elevated temperatures, which, depending on the duration of thermal exposure and light regime, can cause partial to total bleaching and mortality.

Few studies have followed temporal variation in Symbiodinium-octocoral symbioses even though octocorals are among the most abundant cnidarians of Caribbean reef communities, with up to 40 species coexisting in a single coral community (Lasker \& Coffroth 1983, Sanchez et al. 2003). In the octocoral Plexaura kuna, Symbiodinium densities were lowest during the summer months (Lasker 2003), yet the predominant Symbiodinium genotype did not vary over $10 \mathrm{yr}$ of sampling, demonstrating tremendous temporal stability (Goulet \& Coffroth 2003a).

In the present study we monitored temporal patterns in Symbiodinium diversity and cell density in the octocoral Briareum asbestinum (encrusting form). $B$. asbestinum is a gonochoric brooding gorgonian that is widely distributed throughout the Caribbean Sea (Brazeau \& Lasker 1992). Like most Caribbean octocorals, B. asbestinum harbors mainly Clade B Symbiodinium, which is acquired via horizontal transmission during the juvenile stage (LaJeunesse 2002, Goulet \& Coffroth 2004). However, finer level characterization of the symbionts reveals the presence of variation within the Clade B Symbiodinium harbored by B. asbestinum (Santos et al. 2003) and studies of the establishment of the symbiosis indicate that $B$. asbestinum polyps can host other symbiont types shortly after metamorphosis of the planula larva into a polyp (M. A. Coffroth unpubl. data). Moreover, B. asbestinum can shift symbionts after an artificial bleaching event (Lewis \& Coffroth 2004). This raises the question of whether $B$. asbestinum also shows variation after exposure to natural seasonal events and smaller scale stresses. The goal of the present study was to determine whether temporal variation in Symbiodinium taxa and density occur within the octocoral B. asbestinum.

\section{MATERIALS AND METHODS}

Study site and collection of corals. Two populations of 30 Briareum asbestinum colonies were repeatedly sampled from the middle Florida Keys during 2002 and 2003. The Point population was located approximately $30 \mathrm{~m}$ offshore from Long Key in Florida Bay $\left(24^{\circ} 49.949^{\prime} \mathrm{N}\right.$, $80^{\circ} 48.660^{\prime} \mathrm{W}$ ) at a depth of $1.5 \mathrm{~m}$; the Craig Key population was located approximately $150 \mathrm{~m}$ offshore from Craig Key in the Atlantic Ocean $\left(24^{\circ} 49.791^{\prime} \mathrm{N}\right.$, $80^{\circ} 46.743^{\prime} \mathrm{W}$ ) at a depth of $2.0 \mathrm{~m}$. These 2 sites were chosen because they contain high densities of $B$. asbestinum and potentially experience different environmental conditions that may differentiate the coralsymbiont dynamics of the 2 populations. Tissue was collected from the lower third of each colony in June and October 2002 and January, March and June 2003.

Temperature measurements. We monitored in situ seawater temperatures at each site from October 2002 to June 2003 using HOBO H-01-001-01 temperature loggers (Onset Computer Corporation; accuracy within $\pm 0.1^{\circ} \mathrm{C}$ ). Additional temperature measurements from January 1993 to January 2009 were obtained from Florida Bay at the Long Key Buoy (LONF1), which is operated and maintained by the National Oceanic and Atmospheric Administration's (NOAA's) National Data Buoy Center, approximately $2.0 \mathrm{~km}$ from our Point site. These temperatures were used as a proxy for seawater temperature at the study sites when the temperature loggers were not deployed.

We compiled data from the LONF1 buoy corresponding to 12 yr of hourly SST measurements, from January 1994 to December 1995 and from July 1998 to December 2008. Temperature readings from December 1995 to July 1998 were fragmented and therefore were not used. These data were good predictors of the hourly temperatures obtained with the HOBO loggers at Craig and Point from October 20th, 2002 to June 6th 2003 (linear regression: Craig $\mathrm{r}^{2}=0.84, F_{1,1543}=7,996.14 \mathrm{p}<$ 0.001; Point $\mathrm{r}^{2}=0.98, F_{1,1544}=32,702.49, \mathrm{p}<0.001$ ).

Daily minimum and maximum temperatures were analyzed using classical seasonal decomposition (CSD) to remove the seasonal and trend-cycle components. 
The trend-cycle component was estimated using 5 mo weighted centered moving average (Makridakis \& Wheelwright 1989). Graphical inspection of temperature series revealed that the months of January were consistently the coldest during the survey period. We used CSD residuals obtained for the months of January 1995, 1999 and for all Januaries from 2001 to 2008 to test if the winter of 2003 was significantly colder than the other winters within the $12 \mathrm{yr}$ period. To test if the summer of 2002 was significantly warmer, we used residuals obtained for the hottest part of that season (from June until August) for the years of 1994, 1995 and from 1999 to 2007. Because the time series was frequently interrupted during the sampling period, we could not use all available seasons. Residuals were subjected to Kruskal-Wallis ANOVA followed by Bonferroni-corrected pair-wise Mann-Whitney tests.

Characterization of Symbiodinium diversity. The Symbiodinium populations harbored by Briareum asbestinum were distinguished by length variation in domain $\mathrm{V}$ of the chloroplast large subunit of rDNA (cp23S-rDNA) following standard protocols and comparing the resultant fragments to known standards (cp23S-rDNA type, Santos et al. 2003). This technique rapidly identifies Symbiodinium isolates within a phylogenetic framework and allows detection of multiple Symbiodinium cp23S-rDNA types of a single clade in a single sample at very low concentrations (estimated at 10 to 1000 cells, Santos et al. 2003). cp23S-rDNA type is designated by clade and bp size of the cp23S-rDNA fragment. B. asbestinum typically contains Symbiodinium cp23S-rDNA types B178 and/or B184 (i.e. Clade B and a cp23S-rDNA fragment of 178 or $184 \mathrm{bp}$ ), which are analogous to ITS2 type B19 and B1, respectively, based on sequence of the internal transcribed spacer region 2 (ITS2) of nuclear ribosomal DNA (Coffroth \& Santos 2005).

To determine whether cp23S-rDNA type varied with sampling position on the colony, tissue samples were taken from the top, middle and bottom of 10 Briareum asbestinum colonies adjacent to the marked colonies at the Craig Key and Point sites in August 2002. To determine whether Symbiodinium type varied with height above the substrate, colonies were sampled at $<10 \mathrm{~cm}$, between 10 and $20 \mathrm{~cm}$ and at $>20 \mathrm{~cm}$ above the substrate. These samples were collected from marked survey colonies at the Craig Key and Point sites in January 2003. Eight additional colonies that were not included in the annual monitoring were sampled from the Point site to attain a sufficient sample size for the $>20 \mathrm{~cm}$ height.

Determination of Symbiodinium density. To determine symbiont density, an approximately $4 \mathrm{~mm}^{3}$ sample of frozen tissue was macerated in a tissue homogenizer with $5 \mathrm{ml}$ of $0.2 \mu \mathrm{m}$ filtered seawater and passed through a $125 \mu \mathrm{m}$ mesh to remove tissue. A $1 \mathrm{ml}$ aliquot was preserved in $10 \%$ formalin to calculate cell counts and Symbiodinium densities were averaged across 4 hemocytometer counts. Cell densities were computed using the product of length, width and thickness of the tissue samples as an approximation of tissue volume.

\section{RESULTS}

\section{Temperature measurements}

The study sites experienced very similar temperatures over the course of a year and from year to year (Fig. 1). Sampling logistics did not permit sampling during late summer months (Aug and Sep) when water temperature

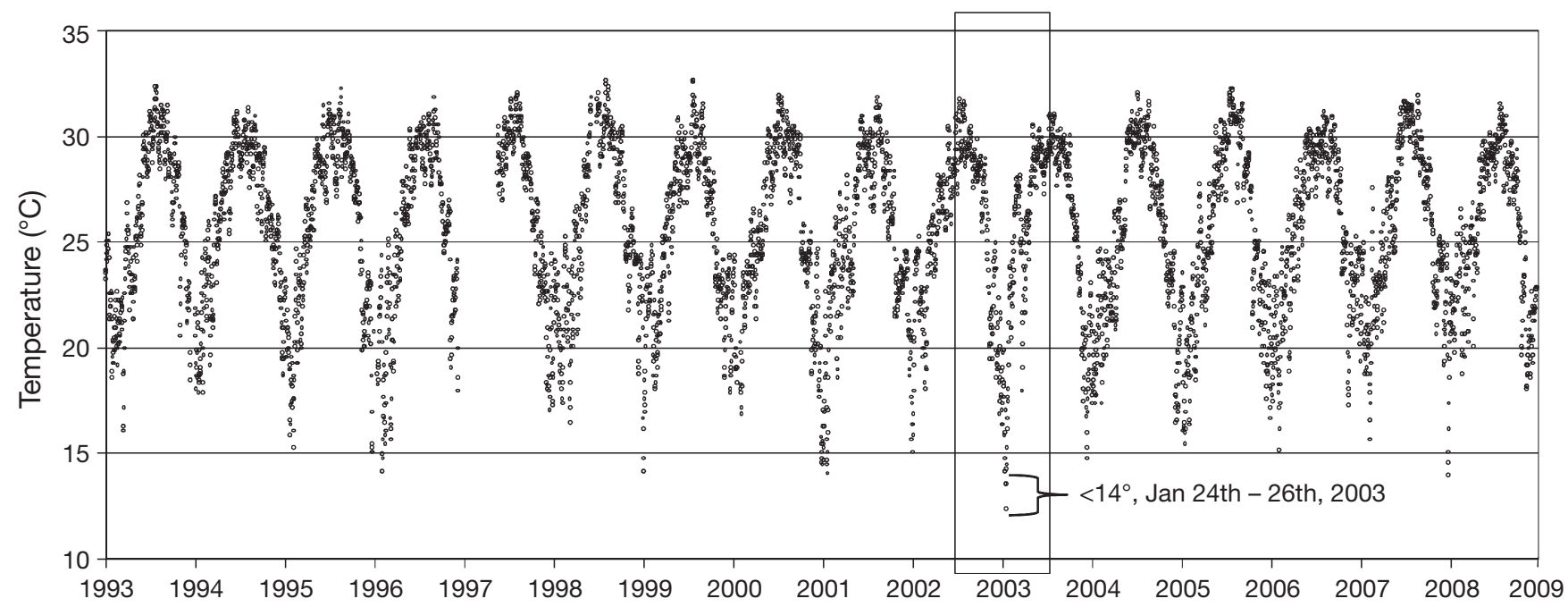

Fig. 1. Minimum daily seawater temperature recorded in Florida Bay at the Long Key Buoy (LONF1) between January 1993 and January 2009. Open rectangle: time period in which the 2 populations of Briareum asbestinum were sampled. The $3 \mathrm{~d}$ in January 2003 (24th to 26th) when seawater temperatures were $<14^{\circ} \mathrm{C}$ are indicated 
is typically greatest. However, the October 2002 sampling occurred before water temperatures began to decrease, which captured the peak of elevated water temperatures (Fig. 1).

Kruskal-Wallis ANOVA employing errors computed for the months of January was highly significant (Pearson's $\chi^{2}=$ 36.65, df $=8, \mathrm{p}<0.001$ ) and Bonferroni corrected ( $\alpha=0.05 / 8=0.00625)$ pairwise Mann-Whitney tests found significant differences between January 2003 and all other months with the exception of January 2001 (Table 1). We also computed the numbers of hourly readings below $14^{\circ} \mathrm{C}$ at the buoy for all months of January from 1993 to 2008. January 2003 was the only month when temperatures actually dropped below $14^{\circ} \mathrm{C}(37 \mathrm{~h})$ and hence this month had a significantly larger number of extreme readings (Pearson's $\chi^{2}=484.02, \mathrm{df}=14, \mathrm{p}<0.001$ ) than the other Januaries within this $15 \mathrm{yr}$ window (Fig. 1). A SST reading of $14^{\circ} \mathrm{C}$ at buoy LONF1 is equivalent to 14.2 to $14.4^{\circ} \mathrm{C}$ at Point and 14.8 to $15.3^{\circ} \mathrm{C}$ at Craig (95\% CIs) hence these sites were slightly warmer. HOBO readings at the sites show that only $8 \mathrm{~h}$ were spent below $14^{\circ} \mathrm{C}$ at Craig and $11 \mathrm{~h}$ at Point for January 2003. However, readings at these sites were taken every $3 \mathrm{~h}$ as opposed to the hourly readings at the buoy.

Kruskal-Wallis ANOVA was also significant for the summer SST data (Pearson's $\chi^{2}=40.16$, df $=10, \mathrm{p}<$ $0.001)$; however, results of the pairwise comparison revealed that the maximum temperatures during the summer of 2002 were not significantly higher than any other year but 2004 (Mann-Whitney $U=3169.50$, Zscore $=2.94, \mathrm{p}<0.005)$.

\section{Characterization of Symbiodinium diversity}

The Symbiodinium assemblages in the 2 Briareum asbestinum populations were dominated by Symbiodinium B178 and were stable over a year period, with only 7 of the 60 monitored colonies experiencing a change in cp23S-rDNA type (Table 2). The remaining colonies harbored exclusively B178 for the duration of study. When symbiont change was observed no clear pattern emerged. Log-linear analysis on a 3-way contingency table revealed that genotype frequencies did not change significantly between populations or over time $\left(\chi^{2}=2.65\right.$, $\mathrm{df}=12, \mathrm{p}=0.99$ ).

Tissue samples taken from different locations within a colony generally contained the same symbiont type.
Table 2. Symbiodinium spp. in Briareum asbestinum. Symbiodinium cp23S-rDNA type within 7 coral colonies that exhibited symbiont variation during the monitoring period from June 2002 to June 2003. Letter before colony number (C: Craig Key; P: Point): source population for each colony. 178/184 indicates periods when both B178 and B184 cp23S-rDNA types were present. The other 54 colonies harbored only cp23S-rDNA type B178 throughout the study. Bold: 184 was present

\begin{tabular}{|lccccccc|}
\hline & \multicolumn{7}{c|}{ Colony designation } \\
& C4 & C14 & P1 & P8 & P9 & P14 & P15 \\
\hline $\mathbf{2 0 0 2}$ & & & & & & & \\
June & 178 & 178 & 178 & 178 & $\mathbf{1 7 8 / 1 8 4}$ & $\mathbf{1 8 4}$ & $\mathbf{1 8 4}$ \\
October & 178 & $\mathbf{1 7 8 / 1 8 4}$ & $\mathbf{1 8 4}$ & $\mathbf{1 8 4}$ & 178 & $\mathbf{1 8 4}$ & 178 \\
$\mathbf{2 0 0 3}$ & & & & & & & \\
January & $\mathbf{1 7 8} / \mathbf{1 8 4}$ & 178 & 178 & 178 & 178 & $\mathbf{1 8 4}$ & 178 \\
March & 178 & 178 & 178 & 178 & 178 & $\mathbf{1 8 4}$ & 178 \\
June & 178 & 178 & 178 & 178 & 178 & $\mathbf{1 7 8} / \mathbf{1 8 4}$ & 178 \\
\hline
\end{tabular}

Additionally, no relationship between height above the substrate and symbiont composition was detected with 31 of the 33 colonies sampled at different heights above the substrate, harboring only Symbiodinium B178.

\section{Symbiodinium density}

Average Symbiodinium sp. concentrations for each sampling period ranged from $3.19 \times 10^{5}$ cells $\mathrm{cm}^{-3}$ (March 2003) to $3.94 \times 10^{5}$ cells cm$^{-3}$ (June 2002) at the 
Craig Key population and from $2.69 \times 10^{5} \mathrm{cells}^{-3}$ (June 2003) to $3.48 \times 10^{5}$ cells cm$^{-3}$ (October 2002) at the Point population. It should be noted that during all sampling events there was no visible difference in the polyp pigmentation of the sampled colonies. However, cell count results revealed that the cell densities in the Craig Key population were consistently higher than in the Point population (repeated measures ANOVA, $\left.F_{1,217}=14.79, p<0.001\right)$. Furthermore, cell densities decreased significantly over the course of the study $\left(F_{4,868}=7.62, \mathrm{p}<0.001\right)$ and this decrease was consistent between populations since the interaction term was non-significant $\left(F_{4,868}=0.28, \mathrm{df}=4, \mathrm{p}=0.892\right)$ (Fig. 2). Bonferroni corrected pairwise comparison using the dependent samples Student's t-test revealed that the significant decrease at the Point population occurred between October 19th, 2002 and January 26th, 2003 (Student's $t=6.30$, df $=57, \mathrm{p}<0.001$ ); and between October 19th, 2002 and March 27th, 2003 at the Craig Key population (Student's $t=4.13, \mathrm{df}=56$, $\mathrm{p}<0.001$ ). The Point and Craig populations lost 22.5 and $18.9 \%$, respectively, of their resident symbionts during these significant decreases. It should be noted that during the January 2003 sampling event, the Craig Key population was sampled on the 23rd, $1 \mathrm{~d}$ before the SST's dropped below $14^{\circ} \mathrm{C}$, whereas, the Point population was sampled on January 26 th, the 3rd consecutive day of SSTs below $14^{\circ} \mathrm{C}$ (Fig.2). As of June 12th, approximately 6 mo after the cold SST event, the colonies at both populations had not recovered to the cell density levels observed before the cold SST event.

Kruskal-Wallis ANOVA was used to test for significant differences in cell counts among genotypes in the months when a change in genotypes occurred (Fig. 3).

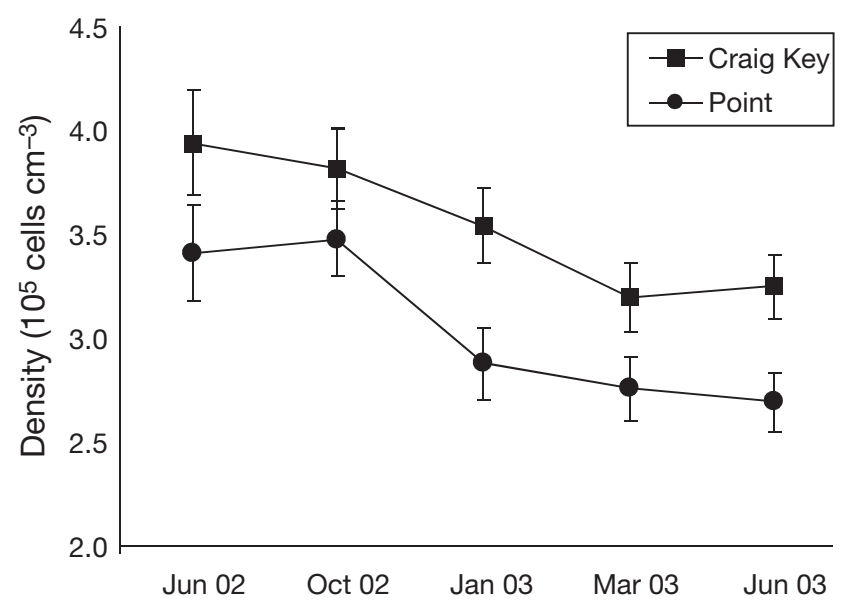

Fig. 2. Symbiodinium spp. Mean cell density over the 5 sampling periods from June 2002 to June 2003. Error bars: $\pm 95 \%$ CI
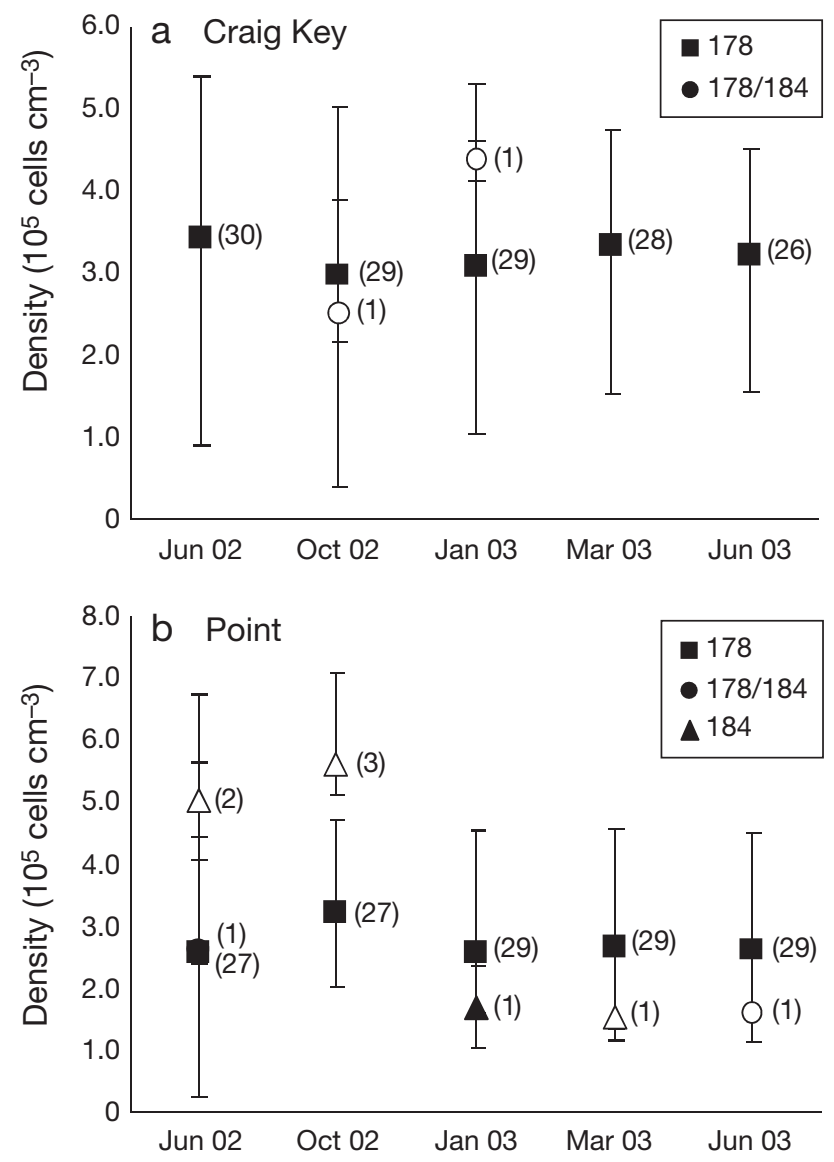

Fig. 3. Symbiodinium spp. Temporal variation in cell density grouped by genotype at the (a) Craig Key and (b) Point populations. Symbols: median; error bars: minimum-maximum ranges. Open symbols: symbols corresponding to genotypes that differed significantly with respect to cell density. Parentheses: sample sizes (n) used in the Kruskal-Wallis ANOVA

Although it appears that colonies with B184 have significantly greater cell densities during many of the sampling events, these results could be an artifact of smaller sample sizes. Greater sampling effort is needed to further test this pattern.

\section{DISCUSSION}

The high correlation between the Long Key Buoy (LONF1), Craig Key and Point temperatures indicate that the buoy data were good predictors of SSTs at our study sites. Thus, corals at the study sites experienced anomalously cold SSTs during January 2003, which corresponded to a significant loss of symbionts in both populations, and repeatedly experienced daily averages that exceeded $31^{\circ} \mathrm{C}$ during the summer of 2002 . Despite the extreme temperature fluctuations that 
occurred throughout the year, these octocorals did not change symbiont composition.

Briareum asbestinum associates with at least 2 types of Clade B Symbiodinium (B178 and B184) with the abundance of each type varying between sites (D. Poland \& M. A. Coffroth unpubl. data). Symbiodinium B178 was the dominant symbiont within $B$. asbestinum at the study sites, but in some samples (3.3 to $6.7 \%$ ) only B184 was detected and in a few others $(3.3 \%)$ mixtures of B178 and B184 were found. Thus, within sites (and within colonies) the Symbiodinium types form a mosaic with no evident patterns of distribution. Furthermore, the small variation in symbiont genotype that was observed, did not correlate with any of the environmental variables investigated. These data corroborate other studies that have found similar longterm stability in symbiont diversity in several octocoral and scleractinian species (Goulet \& Coffroth 2003b, Kirk et al. 2005, Thornhill et al. 2006a,b, Stat et al. 2009). Despite the fact that many of these studies encompassed bleaching events (Goulet \& Coffroth 2003b, Thornhill et al. 2006a, Stat et al. 2009) or diseased corals (Kirk et al. 2005), the overriding trend is one of stability in symbiont composition.

Stability of symbiosis appears to be a common trait among Caribbean octocorals and is supported by the general low level of bleaching experienced by most Caribbean octocoral taxa (Erythropodium and, in some cases, Briareum and Plexaurella, which are notable exceptions). Caribbean octocorals almost exclusively harbor Symbiodinium type B184 (Santos et al. 2003, Goulet \& Coffroth 2004; analogous to ITS2 type B1 of LaJeunesse 2001, 2002) while scleractinians host a variety of Symbiodinium 'types' (LaJeunesse 2002). Those octocorals that do bleach (i.e. Erythropodium and, in some cases, Briareum and Plexaurella) tend to harbor Clade C Symbiodinium (Goulet \& Coffroth 2004, van Oppen et al. 2005). Symbiodinium B184/B1 is characterized as a generalist (LaJeunesse, 2002), but the variability in bleaching seen between octocorals and scleractinians that harbor B184/B1 suggests either a variation in the response of the holobiont to bleaching stressors or variation within Symbiodinium B184. Santos et al. (2004) confirmed fine scale diversity and specificity within the type B184. Future studies should focus on this diversity as a basis for the differences in bleaching in response to a given environmental stressor between octocorals and other cnidarians.

Although Symbiodinium type B184 was relatively rare at our study sites, this type dominates some Briareum asbestinum populations in the Florida Keys (D. Poland pers. comm.) and can often exist with Symbiodinium B178 at background levels (Lewis \& Coffroth 2004), which would account for the few instances of symbiont change observed over the year. For example, Lewis \& Coffroth (2004) found that within B. asbestinum the proportion of Symbiodinium B184 to B178 increased after dark-induced bleaching, demonstrating the potential for change in symbiont composition within a host as the environmental conditions change (as seen in the Montastraea species complex, Rowan et al. 1997, Toller et al. 2001, and in Acropora millepora, Jones et al. 2008). Lewis \& Coffroth (2004) suggested that in this species B184 may be a low-level symbiont type that may be more tolerant of bleaching stressors (Lewis \& Coffroth 2004). In the present study, the colonies harboring B184 often exhibited higher cell densities, but since B184 was often found in combination with B178, it is unclear what cell types contributed to the higher densities.

Coral bleaching in general and the seasonal fluctuations reported in previous studies are often associated with increasing SST (Fitt et al. 2000, Stimson 1997, Brown et al. 1999, Fagoonee et al. 1999, Warner et al. 2002, Lasker 2003, Costa et al. 2005). As noted, the SSTs at the study sites fluctuated from 12.5 to $32.7^{\circ} \mathrm{C}$. There was no temperature related variation in symbiont density in response to the elevated summer SSTs. The elevated summer temperatures of 2002 are comparable with that in 1998 when bleaching in the upright morph of Briareum asbestinum was recorded at sites in the northern and southern Florida Keys, but this was accompanied by a pathogenic infection that lead to high levels of mortality (Harvell et al. 2001). Site differences, $B$. asbestinum morphology, marginally lower temperatures in 2002 compared with 1998 and possibly pathogen abundance may account for the different response. The lack of fluctuation in cell density and symbiont type during the summer months may signify that these holobionts (collected from shallow waters that routinely experience this range of temperatures, Fig. 1) maintain the association over this range of environmental fluctuations. Furthermore, the contrasting results of these 2 studies (Harvell et al. vs. the present study) emphasize that small differences in temperature may be important and suggest that other environmental factors may also exacerbate the effects.

In January 2003 both Briareum asbestinum populations experienced a low-level of bleaching $(\sim 20 \%$ cell loss) in response to anomalously cold SSTs of $<14^{\circ} \mathrm{C}$ for 8 to $11 \mathrm{~h}$. The significant decrease in cell density at the Point population was observed during the January 2003 sampling event, most likely because colonies were sampled on January 26th, the third day of temperatures $<14^{\circ} \mathrm{C}$. A significant decrease in cell density was not detected at the Craig population until March 2003, most likely due to the fact that these colonies were sampled on January 23rd, $1 \mathrm{~d}$ before the temperatures dropped below $14^{\circ} \mathrm{C}$. Although not planned, this sam- 
pling strategy provided insight into the level and duration of cold water stress that causes bleaching in B. asbestinum. The effects of cold water stress on B. asbestinum observed in the present study are concordant with others studies documenting cold water stress on Atlantic and Pacific scleractinian species, which indicate SSTs $<14^{\circ} \mathrm{C}$ lead to the breakdown of the coral-algal symbioses (Shinn 1966, Porter et al 1982, Saxby et al 2003, Hoegh-Guldberg 2005). The present study also provides information concerning the time needed for an octocoral to recover from a low-level bleaching event; as of June 12th, 2003, neither population had recovered to pre-bleaching symbiont densities.

The dramatically different response demonstrated by Briareum asbestinum to the elevated temperatures in 1998 and 2002 indicates how close many corals live to their thermal limits. Considering the magnitude and rate of change forecasted for the tropical marine environment in the near future (IPCC 2007), it is clear that bleaching events will continue and intensify. The present study contributes to an increasing number of investigations that suggest many coral species may not respond to fluctuating environments by changing symbionts and points to the need for more studies like this one (and those of Thornhill et al. 2006a,b, Jones et al. 2008, Sampayo et al. 2008 and Stat et al. 2009) that track the longer term trends of coral-algal symbiosis. The higher Symbiodinium densities retained by the Craig populations (Fig. 2), indicate that there may be significant spatial variation in algal densities in coral populations. We ruled out the possibility that this spatial variation is due to differences in the genotypic composition of the symbionts, but distinguishing between causation due to environmental factors and/or host genotype is beyond the scope of the present study. However, if further experiments demonstrate that higher Symbiodinium densities mean greater resistance to bleaching, and spatial variation in symbiont densities is detected in other coral populations, this will have implications for management and policy strategies in terms of prioritizing areas where synergistic impacts should be mitigated in order to minimize incidence of bleaching.

Acknowledgements. We thank the Florida Keys National Marine Sanctuary for permission to collect and export samples from Florida and Sherwood SCUBA for donation of SCUBA equipment. Special thanks go to the staff of the Keys Marine Laboratory for technical and logistical support and access to temperature data and C. L. Lewis for her assistance in the field. We also thank H. R. Lasker for assistance with the statistical analysis and 4 anonymous reviewers for comments that improved the manuscript. This research was supported by National Science Foundation grant OCE-99-07319 to M.A.C., and M.S.B was supported by a scholarship from CNPq - Brazil.

\section{LITERATURE CITED}

Baker AC (2001) Bleaching of reef corals promotes rapid response to environmental change. Nature 411:765-766

Baker AC (2003) Flexibility and specificity in coral-algal symbiosis: diversity, ecology and biogeography of Symbiodinium. Annu Rev Ecol Evol Syst 34:661-689

Baker AC, Romanski AM (2007) Multiple symbiotic partnerships are common in scleractinian corals, but not in octocorals: comment on Goulet (2006). Mar Ecol Prog Ser 335: $237-242$

Berkelmans R, van Oppen M (2006) The role of zooxanthellae in the thermal tolerance of corals: a 'nugget of hope' for coral reefs in an era of climate change. Proc R Soc Lond B Biol Sci 273:2305-2312

Brazeau DA, Lasker HR (1992) Reproductive success in the Caribbean octocoral Briareum asbestinum. Mar Biol 114: 157-163

Brown BE, Dunne RP, Ambarsari I, Le Tissier MDA, Satapoomin U (1999) Seasonal fluctuations in environmental factors and their influence on symbiotic algae and chlorophyll pigments in four Indo-Pacific coral species. Mar Ecol Prog Ser 191:53-69

Carpenter KE, Abrar M, Aeby G, Aronson RB and others (2008) One-third of reef-building corals face elevated extinction risk from climate change and local impacts. Science 321:560-563

Chen CA, Wang JT, Fang LS, Yang YW (2005) Fluctuating algal symbiont communities in Acropora palifera (Scleractinia: Acroporidae) from Taiwan. Mar Ecol Prog Ser 295: 113-121

Coffroth MA, Santos SR (2005) Genetic diversity of symbiotic dinoflagellates in the genus Symbiodinium. Protist 156: 19-34

Coles SL, Jokiel PJ (1978) Synergistic effects of temperature, salinity and light on the hermatypic coral Montipora verrucosa. Mar Biol 49:187-195

> Costa CF, Sassi R, Amaral FD (2005) Annual cycle of symbiotic dinoflagellates from three species of scleractinian corals from coastal reefs of northeastern Brazil. Coral Reefs 24:191-193

Donner SD, Knutson TR, Oppenheimer M (2007) Modelbased assessment of the role of human-induced climate change in the 2005 Caribbean coral bleaching event. Proc Natl Acad Sci USA 104:5483-5488

> Douglas AE (2003) Coral bleaching-how and why? Mar Pollut Bull 46:385-392

$>$ Fagoonee I, Wilson HB, Hassel MP, Turner JR (1999) The dynamics of zooxanthellae populations: a long-term study in the field. Science 283:843-845

Fitt WK, Warner ME (1995) Bleaching patterns of four species of Caribbean reef corals. Biol Bull (Woods Hole) 189:298-307

Fitt WK, McFarland FK, Warner ME, Chilcoat GC (2000) Seasonal patterns of tissue biomass and densities of symbiotic dinoflagellates in reef corals and relation to coral bleaching. Limnol Oceanogr 45:677-685

> Gleason DF, Wellington GM (1993) Ultraviolet radiation and coral bleaching. Nature 365:836-838

> Glynn PW, D'Croz L (1990) Experimental evidence for high temperature stress as the cause of El Nino-coincident coral mortality. Coral Reefs 8:181-191

- Goulet TL (2006) Most corals may not change their symbionts. Mar Ecol Prog Ser 321:1-7

Goulet TL, Coffroth MA (2003a) Genetic composition of zooxanthellae between and within colonies of the octocoral Plexaura kuna, based on small subunit rDNA and multilocus DNA fingerprinting. Mar Biol 142:233-239 
Goulet TL, Coffroth MA (2003b) Stability of an octocoral-algal symbiosis over time and space. Mar Ecol Prog Ser 250: $117-124$

Goulet TL, Coffroth MA (2004) The genetic identity of dinoflagellate symbionts in Caribbean octocorals. Coral Reefs 23:465-472

> Harvell D, Kim K, Quirolo C, Weir J, Smith G (2001) Coral bleaching and disease: contributors to 1998 mass mortality in Briareum asbestinum (Octocorallia, Gorgonacea). Hydrobiologia 460:97-104

Hoegh-Guldberg O, Fine M, Skirving W, Johnstone R, Dove S, Strong A (2005) Coral bleaching following wintry weather. Limnol Oceanogr 50:265-271

Hughes TP, Baird AH, Bellywood DR, Card M and others (2003) Climate change, human impacts, and the resilience of coral reefs. Science 301:929-933

IPCC (Intergovernmental Panel on Climate Change) (2007) The fourth assessment report of the IPCC. Cambridge University Press, Cambridge

> Jones AM, Berkelmans R, van Oppen MJH, Mieog JC, Sinclair W (2008) A community change in the algal endosymbionts of a scleractinian coral following a natural bleaching event: field evidence of acclimatization. Proc R Soc Lond B Biol Sci 275:1359-1365

Kirk NL, Ward JR, Coffroth MA (2005) Stable Symbiodinium composition in the sea fan Gorgonia ventalina during temperature and disease stress. Biol Bull 209:227-234 (Woods Hole)

Krause GH (1992) Effects of temperature on energy-dependent fluorescence quenching in chloroplasts. Photosynthetica 27:249-252

> LaJeunesse TC (2001) Investigating the biodiversity, ecology, and phylogeny of endosymbiotic dinoflagellates in the genus Symbiodinium using the internal transcribed spacer region: in search of a 'species' level marker. J Phycol 37:866-880

LaJeunesse TC (2002) Diversity and community structure of symbiotic dinoflagellates from Caribbean coral reefs. Mar Biol 141:387-400

Lasker HR (2003) Zooxanthellae densities within a Caribbean octocoral during bleaching and non-bleaching years. Coral Reefs 22:23-26

Lasker HR, Coffroth MA (1983) Octocoral distributions at Carrie Bow Cay, Belize. Mar Ecol Prog Ser 13:21-28

Lewis CL, Coffroth MA (2004) The acquisition of exogenous algal symbionts by an octocoral after bleaching. Science 304:1490-1492

Lyons JM (1973) Chilling injury in plants. Annu Rev Plant Physiol 24:445-466

Makridakis SG, Wheelwright SC (1989) Forecasting methods for management, 5th edn. Wiley, New York

McWilliams JP, Côté IM, Gill JA, Sutherland WJ, Watkinson AR (2005) Accelerating impacts of temperature-induced coral bleaching in the Caribbean. Ecology 86:2055-2060

Muscatine L (1990) The role of symbiotic algae in carbon and energy flux in reef corals. In: Dubinsky Z (ed) Coral reefs. Ecosystems of the world, Vol 25. Elsevier, Amsterdam, p 75-87

Oliver TA, Palumbi SR (2009) Distributions of stress-resistant coral symbionts match environmental patterns at local but not regional scales. Mar Ecol Prog Ser 378:93-103

Porter JW, Battey JF, Smith JW (1982) Perturbation and change in coral reef communities. Proc Natl Acad Sci USA 79:1678-1681

Rodriguez-Lanetty M, Chang SJ, Song JI (2003) Specificity of two temperate dinoflagellate-anthozoan associations from the north-western Pacific Ocean. Mar Biol 143:1193-1199
Rowan R (1998) Diversity and ecology of zooxanthellae on coral reefs. J Phycol 34:407-417

Rowan R, Knowlton N, Baker A, Jara J (1997) Landscape ecology of algal symbionts creates variation in episodes of coral bleaching. Nature 388:265-269

> Sampayo EM, Ridgeway T, Bongaerts P, Hoegh-Guldberg O (2008) Bleaching susceptibility and mortality of corals are determined by fine-scale differences in symbiont types. Proc Natl Acad Sci USA 105:10444-10449

Sanchez JA, McFadden CS, Franc SC, Lasker HR (2003) Molecular phylogenetic analyses of shallow-water Caribbean octocorals. Mar Biol 142:975-987

> Santos SR, Gutierrez-Rodriguez C, Coffroth MA (2003) Phylogenetic identification of symbiotic dinoflagellates via length heteroplasmy in domain $\mathrm{V}$ of chloroplast large subunit (cp23S)-ribosomal DNA sequences. Mar Biotechnol 5:130-140

Santos SR, Shearer TL, Hannes AR, Coffroth MA (2004) Finescale diversity and specificity in the most prevalent lineage of symbiotic dinoflagellates (Symbiodinium, Dinophyceae) of the Caribbean. Mol Ecol 13:459-469

Saxby T, Dennison WC, Hoegh-Guldberg O (2003) Photosynthetic responses of the coral Montipora digitata to cold temperature stress. Mar Ecol Prog Ser 248:85-97

Shinn EA (1966) Coral growth-rate, an environmental indicator. J Paleontol 40:233-240

Stat M, Carter D, Hoegh-Guldberg O (2006) The evolutionary history of Symbiodinium and scleractinian hosts-symbiosis, diversity, and the effect of climate change. Perspect Plant Ecol Evol Syst 8:23-43

Stat M, Loh WKW, LaJeunesse TC, Hoegh-Guldberg O, Carter DA (2009) Stability of coral-endosymbiont associations during and after a thermal stress event in the southern Great Barrier Reef. Coral Reefs 28:709-713

Stimson J (1997) The annual cycle of density of zooxanthellae in the tissue of field and laboratory-held Pocillopora damicornis (Linnaeus). J Exp Mar Biol Ecol 214:35-48

> Thornhill DJ, LaJeunesse TC, Kemp DW, Fitt WK, Schmidt GW (2006a) Multi-year, seasonal genotypic surveys of coral-algal symbioses reveal prevalent stability or postbleaching reversion. Mar Biol 148:711-722

Thornhill DJ, Fitt WK, Schmidt GW (2006b) Highly stable symbiosis among western Atlantic brooding corals. Coral Reefs 25:515-519

Toller WW, Rowan R, Knowlton N (2001) Repopulation of zooxanthellae in the Caribbean corals Montastraea annularis and $M$. faveolata following experimental and diseaseassociated bleaching. Biol Bull (Woods Hole) 201:360-373

Trench RK (1997) Diversity of symbiotic dinoflagellates and the evolution of microalgal-invertebrate symbioses. In: Lessios HA, Macintyre IG (eds) Proc 8th Int Coral Reef Symp. Smithsonian Tropical Research Institute, Panama City 2:1275-1286

van Oppen JH, Palstra FP, Piquet AMT, Miller DJ (2001) Patterns of coral-dinoflagellate association in Acropora: significance of local availability and physiology of Symbiodinium strains and host-symbiont selectivity. Proc R Soc Lond B Biol Sci 268:1759-1767

van Oppen JH, Miego JC, Sánchez CA, Fabricus KE (2005) Diversity of algal endosymbionts (zooxanthellae) in octocorals: the role of geography and host relationships. Mol Ecol 14:2403-2417

- Warner ME, Chilcoat GC, McFarland FK, Fitt WK (2002) Seasonal fluctuations in the photosynthetic capacity of photosystem II in symbiotic dinoflagellates in the Caribbean reef-building coral Montastraea. Mar Biol 141:31-38 